前歯部歯列不整を持つ重度歯周炎の患者に対する 治療の 1 症例について

新潟県開業, *日本大学歯学部保存学教室歯周病学講座

野澤 健, 伊藤公一*

\title{
A Treatment Case Report for Advanced Adult Periodontitis Patient with Abnormal Anterior Tooth Position
}

(Niigata, *Department of Periodontology, Nihon University School of Dentistry)

\section{Takeshi Nozawa, Koichi Ito*}

キーワード：成人性歯周炎，歯列不正， MTM, インプラント

1.はじめに

重度歯周炎と前歯部歯列不正、目歯部咬合崩 壊を伴った症例に対しMTM，インプラントを 行い口腔機能の回復を試みた症例について 報告する。

2.初診

女性 1957年3月21日生れ 37歳

初診日1994年9月12日

主訴：前歯の歯並びが気になる 歯がぐらぐらして噛めない

特記事項 特になし

3.診査、検査所見
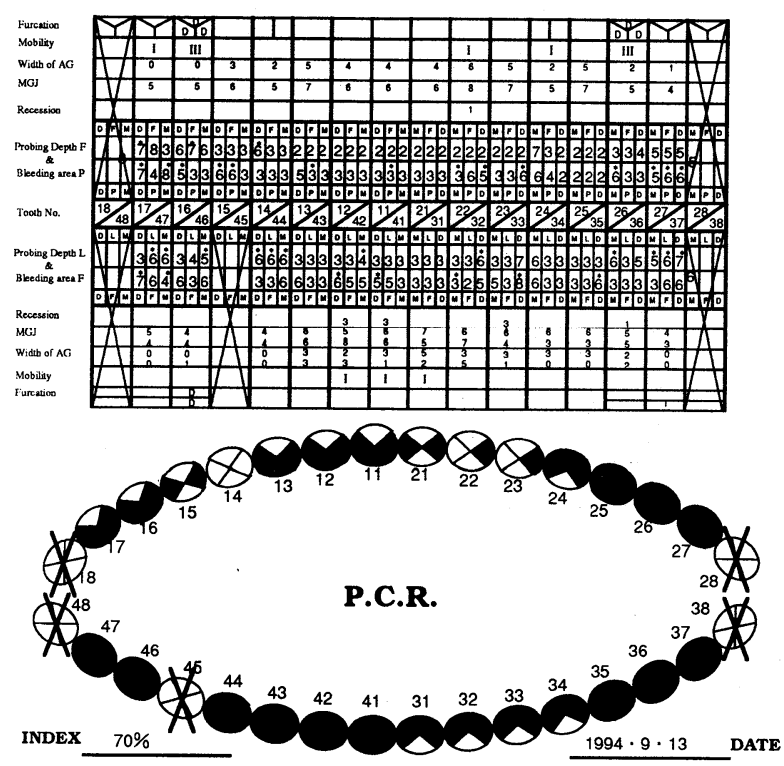

（1）口腔内所見：上下顎の辺縁歯肉、歯間 乳頭部に発赤、腫脹が見られる下顎前歯部に 叢生が見られ22の口蓋側転位、23と24間に 歯間離開が見られる。犬歯関係において アングル2級の状態である。
(2) X 線所見 : 上下顎に多量の歯石沈着が 認められる。特に16、26、46に高度の骨吸収 が認められる。22に歯根膜腔の拡大が認めら れる。

4. 診断: 成人性歯周炎

（若年性歯周炎の既往も疑われる。）

5.治療計画：

（1）初期治療：口腔清掃指導、スケーリング、

ルートプレーニング，16，26，46抜歯

(2) 再評価

（3）歯周外科処置 :

曰歯部を中心に歯肉弁根尖側移動術

34,35 と 45,46 相当部に遊離歯肉移植術

(4) インプラント埋入

45，46相当部（IMZ）インプラント

(5) '上下前歯部のMTM：臼歯部にメタルプ

ロビジョナルを用い固定源にする
（6）バイトプレーン療法
(7) 再評価
(8) 補緅処置:

(17) 16 (15)ブリッジ

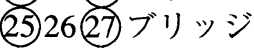

$14,22,34,35$ 焼付陶材冠

45, 46インプラント上部構造

47 金属冠

(9) メインテナンス

治療経過：

1.初診時より動機付けを開始しプラーク

コントロール、スケーリング、

ルートプレーニングを行い

16、26、46の抜歯を行う

2.再評価（歯周治療の評価）PCRは14\%に 減少する。全顎的に臼歯部に $6 \mathrm{~mm}$ 以上の ポケットが存在する、

3.歯周外科手術 1994年11月より1995年3月 にかけて曰歯部において歯肉弁根尖側移動 術を行い34，35部、45、46相当部に遊離歯肉 移植術を行う。 1995年5月に45、46相当部にIMZインプラン 卜埋入を行う。 
4.MTM1995年1月から4月にかけて䀭歯部を 固定源に下顎前歯部叢生、上顎左側側切歯の 口蓋側転位を改善するためMTMを行う 5.再評価（歯周治療の評価） 1995年 6 月 21 口蓋側に $6 \mathrm{~mm} 、 27$ 遠心に $6 \mathrm{~mm}$ のポケット残存

(顎位の評価)

咀嚼運動をシロナソグラフにて測定した ところ咬頭嵌合位（ICP）と中心咬合位 (CO）の不一致が認められた。

6.上顎前歯部審美性改善のため歯周外科

7.顎位の改善のためバイトプレーン療法を行う 8.再評価（歯周治療の再評価）

1996年1月 27遠心に6mmのポケットが残る

(顎位の再評価) ICPとCOのずれは

ほとんどみられない

\section{9.補緅処置}

14，22，34，35，44焼付陶材冠

(17) 16 (15), (25) 26 (27)ブリッジ

36, 37インレー

45, 46IMZインプラント上部構造

47 金属冠

10.メインテナンス

期間は1力月毎とし全顎フッ素塗布と歯肉縁下 洗浄を行い27遠心部にペリオクリンを用いる
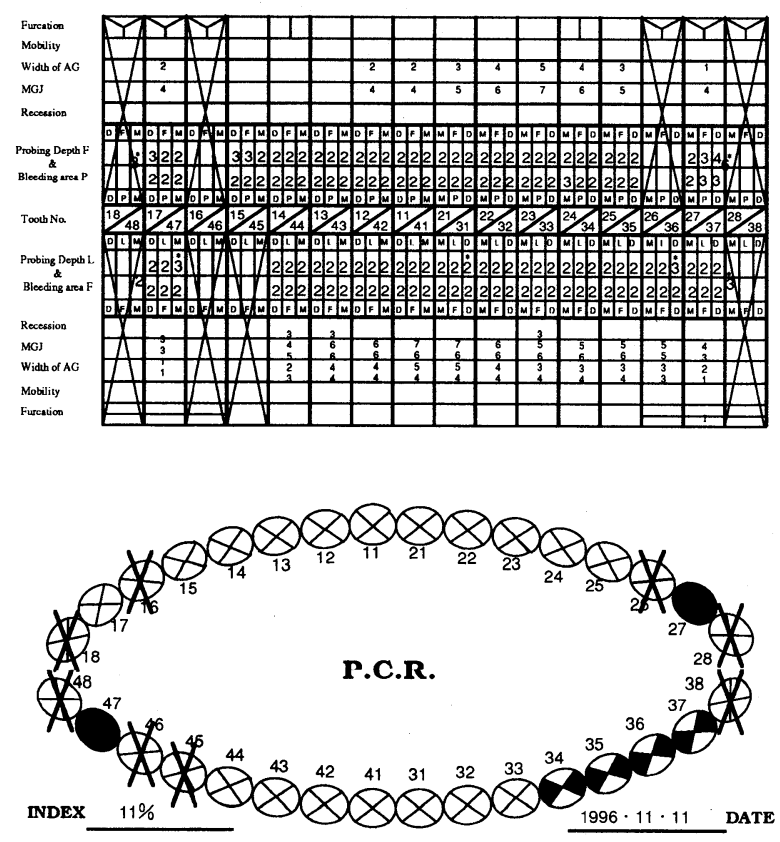

考察

歯列不正を持つ重度歯周炎の全顎治療を行う場 合、患者の口腔清掃の改善を前提としたうえで 歯周治療と矯正処置により歯列の改善を行い 口腔環境の整備をはかったのち修復処置により 機能の改善を図る必要がある。

今回の症例では下顎前歯部の叢生と22の咬合性 外傷の改善と上下前歯部の審美維の改善のため 小矯正をおこなったが、残存歯の骨支持、 そして患者の希望により歯列関係を1級に改善 することは行わなかった そのため左右上顎第 一小歯と下顎犬歯の関係により咀嚼運動に おいて開口運動の制限が起きている。また矯正 期間中、顎位が不安定になったためバイト プレーンにより顆頭安定位を模索した。その後 顎位が安定し，シロナソグラフにおいてもICP の安定性とICPとCOの一致が認められた。 45、46相当部のインプラント処置については メタルプロビジョナルのブリッジの時点で 仮着セメントの溶解が見られた点からもインプ ラントは望ましい処置であったと思われる。 そして顎骨に対する負担軽減のためIMZインプ ラントを用いた。

メインテナンスにおいては全顎的に歯周外科を おこなったため歯根露出が抗こり根面カリエス になりやすく，その予防のため患者のプラーク コントロールの維持と根面に対しフッ素塗布を 行うことが望ましい。

17，27遠心部において埋伏智歯あり，ポケット の改善が困難なためペリオクリン投与を含めた 歯肉縁下プラークコントロールが必要である。 まとめ

前歯部に歯列不正をもつ重度歯周炎の患者の 治療に対し歯肉縁上、縁下の炎症のコント ロールとともに上下歯列弓の改善と機能的、 非機能的な力に対するコントロールが 必要である。

文献

1.村井正大編集 臨床歯周治療学 第1版 三樹企画出版 東京 1988

2.丸山剛郎 臨床生理咬合 第1版 医歯薬出版 東京 1988 